\title{
Fears for Portuguese science as Gulbenkian shifts funding focus
}

London. The Gulbenkian Foundation, Portugal's largest private source of research funding, has decided to reduce its investment in basic research and concentrate on science education and the public understanding of science.

The decision has been criticized by scientists as both discriminating against older researchers - most of those facing redundancy as a result are more than 45 years old - and a blow for research in a country that spends less than one per cent of its gross domestic product on research and development.

But officials at the foundation describe the changes as a "necessary restructuring". They promise to leave open the laboratory facilities at the Gulbenkian Institute of Science, a biomedical research centre at Oeiras, north of Lisbon.

The US\$2-billion foundation is part of the legacy of Calouste Gulbenkian, an Armenian-born British citizen who made a fortune arranging deals between British oil companies and Middle Eastern sheikhdoms between the two world wars. Although most of the foundation's annual spending goes on arts and education, US\$7 million a year currently goes to science.

Under the new arrangements, due to be implemented early in 1998, the 24 researchers at the Gulbenkian Institute will be reduced to a core group of six, concentrating on research in molecular biology, developmental biology and neurobiology. They will also be required to teach and to take part in new activities including communicating science to the public and research methodology to doctors.

"We are not downgrading science," insists João Caraça, director of science at the Gulbenkian Foundation. "But we have to be realistic. We cannot be the ministry of science". Caraça acknowledges that the advancing years of a number of the institute's staff contributed to the decision to reorganize. But he says any further delay might have posed further difficulties.

Critics such as João Monjardino, a Portuguese researcher who is now reader in cell studies at Imperial College in London, argue that the reorganization will terminate "high quality research", as well as the careers of some high quality researchers. "Portugal has a fragile scientific organization and can ill afford the loss of these scientists," he says.

Caraça denies that the foundation is about to abandon the institute's staff. The oldest researchers asked to leave will be offered early retirement, he says. The remainder will be helped to find new jobs in Portugal's state universities. Ehsan Masood

\section{Call for Europe to 'revitalize efforts' in basic research}

Munich. Europe needs to reinvigorate its commitment to science if it is effectively to compete internationally, according to the European Science Foundation (ESF), the Strasbourg-based association of national funding agencies from 21 countries.

A position paper on the European Commission's Fifth Framework Programme, due to be launched in 1998, avoids detailed discussion of how the programme might be structured to meet the complex political demands laid out in the Maastricht treaty, or how much money should be allocated to it.

It focuses instead on a scientific agenda that considers both short-term and longterm aims, based on five main themes that it says are crucial to social and economic development in Europe after the turn of the century: information and communications technologies, industrial technologies for complex systems (including, for example, energy systems), molecular mechanisms in health and life, sustainable use of the environment, and a social sciences programme.

In common with the German position paper (see Nature 381, 634; 1996), that from the ESF Fricker: offering ESF's ESF suggests that services to Brussels. the commission

should delegate the management of some of its research programmes to national agencies. It also suggests a two-stage application procedure, with applicants being required initially to present merely a summary of their proposals, thus saving applicants' time and reducing the burden on reviewing panels.

The ESF also attempts to define its own future role in European research. The foundation, which has been quietly but successfully running scientific networks, workshops and small science programmes for the past 21 years, has recently been trying to carve out a wider role for itself in Europe (see Nature 366, 193; 1993), based on the expertise within its scientific standing committees and its wide networks of contacts with basic researchers throughout Europe.

Analyses prepared by ESF standing committees identify many scientific and technological areas that, the foundation says, would benefit from research carried out at the European level. But its position paper stresses that the overall programme can succeed only if a small number of goals are set.

The foundation says that task forces set up by Edith Cresson, the research commissioner, to promote coordination of themes such as vaccine development across different research programmes, should improve the efficiency with which these goals are met. But it suggests that no new task forces should be created until experience has shown how they can work most effectively.

The position paper says that defending Europe's basic research base will be helped by the continuation of the Fourth Framework Programme's Training and Mobility of Researchers (TMR) programme, which supports fellowships for scientists to work in other countries.

But the ESF says the TMR programme should be expanded to promote the development of specific skills, such as mathematical modelling and algorithms for industrial application. It should also include a return fellowship scheme, similar to that offered by the German Humboldt Foundation, so that scientists can return later to the host laboratory to reinforce the skills learnt.

Peter Fricker, the ESF's secretary general, has asked Cresson for more discussions on how the foundation could help in the development of the Fifth Framework Programme. "We believe that we have a lot to offer", he says.

- Sweden wants the European Union to take special measures to support applications from small and medium-sized enterprises (SMEs) for research grants under the Fifth Framework Programme (FP5), arguing that such organizations lose out because the current system does not adequately consider their needs.

In its position paper on FP5, Sweden points out that SMEs have a vital role in the future growth of the European economy. But, it says, if they want financial support for research and development, they have to spend an excessive amount of time preparing detailed proposals.

Furthermore, the delay between application and start of project is too long for SMEs, given the competitive environment in which they operate. A special SME unit should be created within FP5, says Sweden, to help ease these problems. Such a unit should also be able to transfer applications from one programme to another.

Sweden also suggests that the commission should give greater encouragement to projects with only two or three partners rather than award grants on the apparent basis of "the more the merrier" - arguing that the current average of five or six partners for each application places an undue burden on project coordinators.

Alison Abbott 